\title{
Medicinal plants used in traditional medicine by Oromo people, Ghimbi District, Southwest Ethiopia
}

\author{
Balcha Abera
}

\begin{abstract}
Background: Ethiopia is one of the six centres of biodiversity in the world with several topographies, climatic conditions and various ethnic cultures. Ethnobotanical study is a real and encourageable in rich biological resource areas for medicinal plant identification, documentation, ranking, conservation and sustainable usages. The purpose of this study was to identify the most effective medicinal plants for specific treatment through priority ranking and to assess the status of the transfer of Traditional Botanical Knowledge (TBK) based on age groups and educational levels.
\end{abstract}

Methodology: Ethnobotanical data were collected using field observation and semi-structured interview, A total of 30 key informants and 165 community members were interviewed and data on medicinal plant species and associated knowledge were recorded, quantified and verified using several preference ranking methods.

Results: The study revealed a total of 49 medicinal plant species (belonging to 31 families and 46 genera) used to treat various human ailments, the majority of which 40 (81.6\%) species were collected from wild while the rests from home garden. Herbs constituted the largest growth habit (18 species, 37\%) followed by trees (16 species, $32 \%)$ and shrubs (15 species, 31\%). Leaf ' 17 (35\%) is the plant part widely used followed by root 13 (27\%), leafy-stem 5 (10\%), and seed 6 (12\%). Oral administration was the dominant route (63\%), followed by dermal route (22\%) and nasal (11\%). The highest number of plant species being used for infectious (48\%) followed by two or more diseases and non-infectious disease. Of five and seven medicinal plants of preference ranking the highest ranks were given first for Croton macrostaychus used for malaria treatment and for Prunus africana as "rare" for immediate collection and use in the traditional treatment. Significantly higher average number of medicinal plants $(p<0.05)$ were reported by informants of higher institution $(14.3 \pm 34)$ and adult age groups $(11.6 \pm 43)$.

Conclusion: The Ghimbi people possess rich ethno-medicinal knowledge. This study can be used as a basis for developing management plans for conservation, sustainable use and drug development.

Keywords: Ethnobotany, Traditional knowledge transfer, Preference ranking, Oromia, Ethiopia

\section{Introduction}

About $85 \%$ of world population uses herbal medicines for prevention and treatment of diseases, and the demand is increasing in developed and developing countries [1]. Some $25 \%$ of drugs contain compounds obtained from higher plants [2]. Moreover, the investigation of herbal drugs from plants to treat AIDS, cancer, and malaria, chronic complaints such as rheumatism, arthritis and asthma have been reported [3-5]. Herbal remedies are enjoying widespread popularity throughout the world

Correspondence: balcha_abera@yahoo.com

Department of Biology, College of Natural Sciences, Jimma University, Jimma, Ethiopia
$[6,7]$. However, only $10 \%$ of medicinal plant species is cultivated today while the larger majority being left under wild stands threat $[8,9]$.

Ethiopia is endowed with a diverse biological resources including about 6, 500 species of higher plants, with approximately $12 \%$ endemic, hence making it one of the six plant biodiversity rich regions [10]. Of these, more than $62.5 \%$ of the forest area are found in southwest region of Ethiopia [11] where most of the medicinal plants are confined [12] and have been used as a source of traditional medicine to treat different human and livestock ailments $[13,14]$. Use and management of many medicinal plants in Ghimbi district has been reported by [15]. However, this

\section{Biomed Central}

(c) 2014 Abera; licensee BioMed Central Ltd. This is an Open Access article distributed under the terms of the Creative Commons Attribution License (http://creativecommons.org/licenses/by/2.0), which permits unrestricted use, distribution, and reproduction in any medium, provided the original work is properly credited. 
former study does not provide sufficiently detailed information on the status of Traditional Botanical Knowledge (TBK) transfer from generation to generation based on Oromo Gada system age groups and educational levels as wells as on the ranking of most potential medicinal plants for specific disease treatment in the study area. The present study was therefore to identify those potential and popular medicinal plant species used for the treatment of various diseases in Ghimbi area by Oromo community.

\section{Description of the study area}

Ghimbi District is situated in West Wollega Zone, Oromia National Regional State, $441 \mathrm{~km}$ southwest of Addis Ababa, bounded by East Wollega zone in the East, Lalo Assabi district in West and Guyi district in South and Amhara Reguional estate in the North. Astronomically, the district is located between $90^{0} 109^{0} 17^{1}$ North latitude and $35^{0} 44^{1}{ }_{3} 36^{0} 09^{1}$ East longitude. Generally the district has a total area of $1172 \mathrm{Km}^{2}$.

Ghimbi is one of the 21 districts in the Zone having 31 administrative peasant associations or Kebels. Ghimbi is the Capital of the District. Metrological data taken from National Metrology Service (Addis Ababa) indicates that the major rainy seasons in the district include spring (May), summer (June-August) and autumn (September -October). Average annual temperature of the district is about $20^{\circ} \mathrm{C}$ while average annual rainfall of the district was 600$12000 \mathrm{~mm}$. The study area is found within the range of 1600- 2500masl. This variation in altitude resulted in variability in climate, vegetation types, and cropping system.

Based on the 1994 National census the total population of the District was about 79, 313 of which 38, 976 are males and 40, 337 are females. Rural peoples of the District lead their life on cropping and livestock rearing. The major ethnic composition of population of the District is Oromo (99\%), Amhara, and Guraghe, and other ethnic groups of very few populations. Afan Oromo which is the official language of the state region is the most (major) spoken language in the zone. Amarigna (the second most spoken language in the zone), and Guragigna are also spoken by few populations in the zone [16]. According to Ghimbi District Health Station the healthcare coverage of the study area was $70 \%$ and the major disease categories recorded by the office (2007-2008) were infectious, metabolic, nervous and spiritual specifically such as malaria, stomachace, Gastritis, Diarrhoea, sexually transmitted diseases, cancer, Tuberculosis (TB), skin infection, blood pressure, Anaemia and other helmenthsis and conjunctivitis.

\section{Materials and methods}

\section{Reconnaissance survey and study site selection}

Prior to reconnaissance survey an official letter was received from Jimma University Ethical Review Committee
(ERC) while verbal informed consent was obtained from each informant who was participating during the study period. A reconnaissance survey was conducted from September 1-30, 2009 in Ghimbi District (Figure 1) and determined to include six study sites (peasant associations) namely Gambella Assabi, Gaga'o Kare, Fatagami Hujuka, Wajeti supe, Dongoro Dissi, and Harojjii Hagamsa. The study sites were selected based on the prior information gathered from community leaders, knowledgeable elders, health workers, and number of traditional healers in the area, Therefore, the study was carried out in three attitudinally varying study sites. Areas with lower altitude [(1600-1800 masl) (Gambella Assabi)] is located to the southeast of Ghimbi town, medium altitude [(18002000masl) (Gaga'o Kare, Fatagami Hujuka, Wajeti supe)] is located to southwest of Ghimbi town, high altitude [(>2000 masl) Dongoro Dissi, Harojjii Hagamsa )] is located at the North of Ghimbi town.

\section{Informant selection}

The informants were identified with the help of Kebele leaders, Developmental Agents (DAs) and knowledgeable elders. Thirty traditional healers ( 22 men and 8 women) 5 to 6 from each study site with the age of 30 and above were included as key informants to obtain pertinient information while less than 30 age groups were considered to determine the status of knowledge transfer from elders.

\section{Data collection}

Ethnobotanical data was collected from November 2009 to February 2010 on three field trips made to the site based on methods given by $[17,18]$. Accordingly, semistructured interviews and field observation with informants were employed to obtain indigenous knowledge of the local community. Interviews and discussions were based on, around a checklist of questions prepared before hand in English, and translated to Afan Oromo. Data on medicinal plants and their local names, part(s) used, methods of preparation and preservation, route of application, diseases treated and threat status were recorded at the spot with data recorder. Other relevant information were recorded by repeated inquiries at different times with the same informants to check the accuracy of information obtained and information was recorded. Finally, the specimen were collected, pressed, and dried for further identification and description.

To determine the transfer of Indigenous knowledge from generation to generation on medicinal plants use in the study area a total of 60 and 45 informants (fifteen each from 3 gada age groups $(9-17,18-24,25-31)$ and from 3 educational levels $(1-4,4-8,>8$ grades) were selected from the family of traditional healers al least through naming of medicinal plants. 


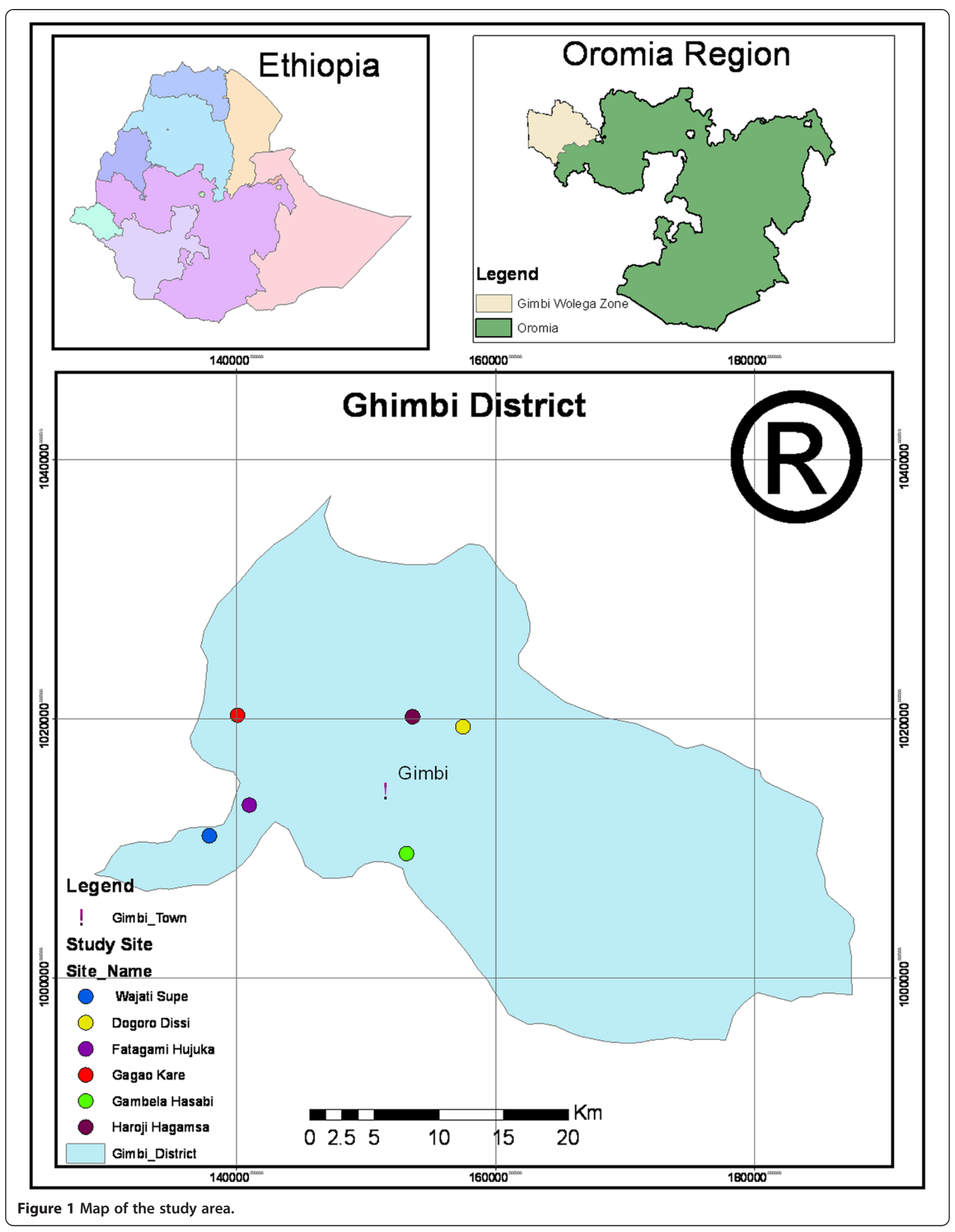




\section{Specimen identification}

Preliminary identification was done in the field by using manuals and unidentified specimens were identified using herbarium materials, experts, and taxonomic keys in the various volumes of the Flora of Ethiopia and Eritrea (19-25). The collected specimens with voucher numbers, family, species and vernacular names, dates and sites of collection were recorded and deposited at the Jimma Herbarium and National Herbarium (Addis Ababa University).

\section{Data analysis}

Microsoft Excel spreadsheet software was used to determine the proportions on growth habit, plant part(s) used, condition of medicinal plants, mode of administration and categories of diseases.

The collected ethnobotanical data on indigenous knowledge transfer (or number of medicinal plants reported by young age and educational groups) were entered into SPSS version 16.0 and summarized using descriptive statistical methods (percentage, table, chart, graphs). The presence and absence of significant differences between age and educational levels (at 95\% confidence level) were checked using one way analysis of variance (ANOVA) with the assistance of software SPSS. The association between knowledge transfer versus age and educational levels were checked using Pearson chi-square test at 5\% level of significance.

\section{Preference ranking}

Preference ranking was used to rank the methods of preparation and preservation, popular medicinal plants and medicinal plants used in the treatment of malaria in the study area [17]. Each variable was ranked by 12 selected informants. All informants were oriented on each variable and asked to mark the highest value (10) for most preferred and the lowest value (1) for the least preferred on preparation and preservation methods, degree of popular medicinal plants and the healing potential of individual medicinal plants (used in the treatment of malaria). Finally, the values were summed up; ranked and illustrated using tables.

\section{Paired comparison}

Pair comparison was used for evaluating the degree of preference of 6 selected medicinal plants reported from the study area in treating Gonorrhoea (Table 1). A list of pairs of selected items with all possible combinations was made and sequence of the pairs and the order within each pair was randomized and presented to selected informants following Martin (17) and their responses were recorded and total scores was summed using the following formula: $n(n-1) / 2, n=$ the number of medicinal plants being compared.

\section{Fidelity level index}

Fidelity level index (FL) is used to quantify the importance of a given species for a particular purpose in a given cultural group. In this study, FL was used to determine the relative healing potential of 4 medicinal plants against human ailments based on the proportion of informants agreement on the use of a given medicinal plant against a given ailment category. The formula used was as follows: $\mathrm{FL} \%=\mathrm{lp} / \mathrm{lu} \times 100, \mathrm{FL} \%$ - Percentage of Fidelity Level, lp - the number of informants who independently indicated the use of the species for the same major ailments, lu - the total number of informants who mentioned the plant for any major ailment [19].

\section{Results}

Medicinal plant species diversity and origin

A total of 49 medicinal plants were reported by the local healers from the study area as being used for treatment in the area. These plants are distributed in 43 genera and 31 families. Family Fabaceae was represented by 5 species followed by 4 species of Asteraceae and Lamiaceae each and 3 species of Euphorbiaceae. Six families were represented by 2 species while the remaining families were represented by one species. Of these, 40 (81.6\%) species were reported from the wild while the rests were from home garden cultivated by the community (Table 1 ).

\section{Growth habit}

Analysis of growth forms of these medicinal plants revealed that herbs constitute the largest category (18 species, $37 \%$ ) followed by trees (16 species, $32 \%$ ) and shrubs (15 species, $31 \%$ ).

\section{Plant part(s) used}

Plant part(s) used for medicinal purposes indicated that Leaf $17(35 \%)$ is the plant part widely used followed by root $13(27 \%)$, leafy-stem $5(10 \%)$ and seed $6(12 \%)$, while the rest include bark $5(10 \%)$, flower $1(2 \%)$, bulb $1(2 \%)$, and tuber $1(2 \%)$.

\section{Medicinal plants condition}

The local healers of the study area employ several collections of plant conditions. Thirty four (44.8\%) preparations are made from fresh form, followed by dry 27 (35.5\%) and both dry and fresh 15 (19.7\%).

\section{Knowledge of local healers on preparation methods}

The local healers employed several methods of preparation of traditional medicines from plants. Powdering and pounding were the most frequently used methods of traditional medicine preparation in the study area as ranked by healers (Table 2). According to the local healers, both pounding and powdering as a strategy permit to preserve the plant materials that are not available both in dry and 
Table 1 Medicinal plant used for the treatment of human diseases; scientific name, local name, Habit, part(s) used, method of preparation, administration route and diseases treated

\begin{tabular}{|c|c|c|c|c|c|c|c|}
\hline Voucher number & $\begin{array}{l}\text { Family, Genera, species } \\
\text { names }\end{array}$ & Local names & $\begin{array}{l}\text { Growth } \\
\text { habit }\end{array}$ & $\begin{array}{l}\text { Plant type, } \\
\text { cultivated/wild }\end{array}$ & $\begin{array}{l}\text { Part(s) used and preparation } \\
\text { method }\end{array}$ & $\begin{array}{l}\text { Administration } \\
\text { route }\end{array}$ & Disease(s) treated \\
\hline BA & \multirow[t]{2}{*}{ Alliaceae, Allium sativum L. } & \multirow[t]{2}{*}{ Qullubbii } & \multirow[t]{2}{*}{$\mathrm{H}$} & \multirow[t]{2}{*}{$\mathrm{D}$} & \multirow{2}{*}{$\begin{array}{l}\text { Bulb of A. sativum and rhizome of } \\
\text { Ginger officinale are pounded and } \\
\text { eaten with honey. }\end{array}$} & \multirow[t]{2}{*}{ Oral } & \multirow[t]{2}{*}{ Malaria } \\
\hline 78 & & & & & & & \\
\hline BA & \multirow{2}{*}{$\begin{array}{l}\text { Aloaceae, Aloe monticola } \\
\text { Reynolds }\end{array}$} & \multirow[t]{2}{*}{ Hargisa } & \multirow[t]{2}{*}{$\mathrm{H}$} & \multirow[t]{2}{*}{ W } & \multirow{2}{*}{$\begin{array}{l}\text { Root is pounded and mixed with } \\
\text { cold water and local alcohol (tella) }\end{array}$} & \multirow[t]{2}{*}{ Oral } & \multirow[t]{2}{*}{ Anthrax } \\
\hline 45 & & & & & & & \\
\hline BA & \multirow{2}{*}{$\begin{array}{l}\text { Aloaceae, Aloe macrocarpa } \\
\text { Tod }\end{array}$} & \multirow[t]{2}{*}{ Hargisa } & \multirow[t]{2}{*}{$\mathrm{H}$} & \multirow[t]{2}{*}{ W } & \multirow{2}{*}{$\begin{array}{l}\text { Leaf of } A \text {. macrocarpa is powdered } \\
\text { and mixed with honey }\end{array}$} & \multirow[t]{2}{*}{ Oral } & \multirow[t]{2}{*}{ Wart } \\
\hline 52 & & & & & & & \\
\hline BA & \multirow{2}{*}{$\begin{array}{l}\text { Amaranthaceae, Amaranthus } \\
\text { caudatus L. }\end{array}$} & \multirow[t]{2}{*}{ lyyaasuu } & \multirow[t]{2}{*}{$\mathrm{H}$} & \multirow[t]{2}{*}{ W } & \multirow[t]{2}{*}{ Leaf is pounded and boiled. } & \multirow[t]{2}{*}{ oral } & \multirow[t]{2}{*}{ Diarrhea } \\
\hline 6 & & & & & & & \\
\hline BA & \multirow{4}{*}{$\begin{array}{l}\text { Apocynaceae, Carissa } \\
\text { spinarum L. }\end{array}$} & \multirow[t]{4}{*}{ Hagamsa } & \multirow[t]{4}{*}{$\mathrm{SH}$} & W & Fresh root of C. spinarum is & Oral & Impotence \\
\hline 24 & & & & & $\begin{array}{l}\text { pounded and mixed with tella (local } \\
\text { alcohol). }\end{array}$ & & Gonorrhea, \\
\hline & & & & & & & Stomachache \\
\hline & & & & & & & Headache \\
\hline BA & Asteraceae, Acmella caulirhiza & Gutichaa & $\mathrm{H}$ & W & Flower of A. Caulirhiza is chewed & Oral & Tonsillitis \\
\hline 21 & & & & & and spitted on tonsillitis & & \\
\hline BA & Asteraceae, Artemisia & Ariti & $\mathrm{H}$ & W & Crushed fresh root of A. abyssinica is & Oral Nasal & Evil spirit \\
\hline 35 & abyssinica & & & & $\begin{array}{l}\text { homogenized in water and the } \\
\text { patient smell and drink }\end{array}$ & & \\
\hline & Sch.Bip.ex.Rich/ & & & & & & \\
\hline Voucher number & $\begin{array}{l}\text { Family, Genera, species } \\
\text { names }\end{array}$ & Local names & $\begin{array}{l}\text { Growth } \\
\text { habit }\end{array}$ & $\begin{array}{l}\text { Plant type, } \\
\text { cultivated/wild }\end{array}$ & $\begin{array}{l}\text { Part(s) used and preparation } \\
\text { method }\end{array}$ & $\begin{array}{l}\text { Administration } \\
\text { route }\end{array}$ & Disease(s) treated \\
\hline BA & Asteraceae, Echinops & Qabarichoo & $\mathrm{H}$ & W & Pounded dry root is mixed with & Oral & Toothache \\
\hline 77 & & & & & & & vomiting \\
\hline & & & & & & & Headache \\
\hline BA & Asteraceae, Guizotia scabra & Adaa & $\mathrm{SH}$ & W & Leaf of G. scabra is squeezed and & Dermal & Wound \\
\hline 53 & & & & & & & \\
\hline BA & Brassicaceae, Coronopus & Surumaa & $\mathrm{SH}$ & W & leafy-stem of $C$. didymus is & Oral & Bone fracture \\
\hline 25 & & & & & $\begin{array}{l}\text { collected and dried in sunlight, } \\
\text { crushed and mixed with soup of } \\
\text { sorghum }\end{array}$ & & \\
\hline BA & Cactaceae, Opuntia ficus & Nimi & $\mathrm{T}$ & W & leaf of O. Ficus-indica is collected & fumigation & Kill malarial vectors \\
\hline 38 & & & & & $\begin{array}{l}\text { With small node and fumigated in } \\
\text { the house }\end{array}$ & & \\
\hline
\end{tabular}


Table 1 Medicinal plant used for the treatment of human diseases; scientific name, local name, Habit, part(s) used, method of preparation, administration route and diseases treated (Continued)

\begin{tabular}{|c|c|c|c|c|c|c|c|}
\hline Voucher number & $\begin{array}{l}\text { Family, Genera, species } \\
\text { names }\end{array}$ & Local names & $\begin{array}{l}\text { Growth } \\
\text { habit }\end{array}$ & $\begin{array}{l}\text { Plant type, } \\
\text { cultivated/wild }\end{array}$ & $\begin{array}{l}\text { Part(s) used and preparation } \\
\text { method }\end{array}$ & $\begin{array}{l}\text { Administration } \\
\text { route }\end{array}$ & Disease(s) treated \\
\hline $\mathrm{BA}$ & \multirow{2}{*}{$\begin{array}{l}\text { Capparidaceae, Crateva } \\
\text { adansonii D.C. Prodr }\end{array}$} & \multirow[t]{2}{*}{ Qolladii } & \multirow[t]{2}{*}{$\mathrm{SH}$} & \multirow[t]{2}{*}{ W } & \multirow{2}{*}{$\begin{array}{l}\text { Dried root of } C \text {. adansonii } \\
\text { powdered, mixed with water }\end{array}$} & \multirow[t]{2}{*}{ Oral } & \multirow[t]{2}{*}{ Gonorrhoea } \\
\hline 4 & & & & & & & \\
\hline BA & \multirow{2}{*}{$\begin{array}{l}\text { Capparidaceae, Ritchiea } \\
\text { albersii Gilg }\end{array}$} & \multirow[t]{2}{*}{ Arbuu } & \multirow[t]{2}{*}{$\mathrm{T}$} & \multirow[t]{2}{*}{ W } & \multirow{2}{*}{$\begin{array}{l}\text { Drops from stem and tied on the } \\
\text { wound } \mathbf{S e e d} \text { pounded and mixed } \\
\text { with tea/ } \mathrm{H}_{2} \mathrm{O}\end{array}$} & \multirow[t]{2}{*}{ Oral } & \multirow[t]{2}{*}{ Cough } \\
\hline 27 & & & & & & & \\
\hline BA & \multirow{2}{*}{$\begin{array}{l}\text { Combretaceae, Combertum } \\
\text { paniculatum Vent }\end{array}$} & \multirow[t]{2}{*}{ Baggii } & \multirow[t]{2}{*}{$\mathrm{SH}$} & \multirow[t]{2}{*}{ W } & \multirow{2}{*}{$\begin{array}{l}\text { Bark latex of } C \text {. paniculatum is } \\
\text { pounded and mixed with soda and } \\
\text { creamed on affected skin. }\end{array}$} & \multirow[t]{2}{*}{ Dermal } & \multirow[t]{2}{*}{ Ringworm } \\
\hline 7 & & & & & & & \\
\hline Voucher number & $\begin{array}{l}\text { Family, Genera, species } \\
\text { names }\end{array}$ & Local names & $\begin{array}{l}\text { Growth } \\
\text { habit }\end{array}$ & $\begin{array}{l}\text { Plant type, } \\
\text { cultivated/wild }\end{array}$ & $\begin{array}{l}\text { Part(s) used and preparation } \\
\text { method }\end{array}$ & $\begin{array}{l}\text { Administration } \\
\text { route }\end{array}$ & Disease(s) treated \\
\hline$\overline{B A}$ & \multirow{2}{*}{$\begin{array}{l}\text { Crassulaceae, Kalanchoe } \\
\text { densiflora Rolfe }\end{array}$} & \multirow[t]{2}{*}{ Endahula } & \multirow[t]{2}{*}{$\mathrm{H}$} & \multirow[t]{2}{*}{ W } & \multirow{2}{*}{$\begin{array}{l}\text { Leaves of } K \text {.densiflora is squeezed, } \\
\text { and its drop is dropped on the } \\
\text { wound }\end{array}$} & \multirow[t]{2}{*}{ Dermal } & \multirow[t]{2}{*}{ Gonorrhea } \\
\hline 61 & & & & & & & \\
\hline BA & \multirow{2}{*}{$\begin{array}{l}\text { Cucurbitaceae, Cucurbita } \\
\text { pepo L. }\end{array}$} & \multirow[t]{2}{*}{ Buqqee } & \multirow[t]{2}{*}{$\mathrm{H}$} & \multirow[t]{2}{*}{ D } & Seed powder is mixed with water & Oral & Gonorrhea \\
\hline 67 & & & & & & & \\
\hline BA & Euphorbiaceae, Croton & Bakkannisa & $\mathrm{T}$ & W & Powdered leafy-stem of $C$. & Dermal & Wound \\
\hline 38 & macrostachyus Del. & & & & $\begin{array}{l}\text { macrostachyus is mixed with } \mathrm{H}_{2} \mathrm{O} \\
\text { and butter and filtered finally. }\end{array}$ & Oral & Malaria \\
\hline & & & & & & Oral & Gonorrhea \\
\hline BA & Euphorbaceae, & Adaamii & $\mathrm{T}$ & W & Bark decoction is taken & Oral & gastro-intestinal, Ascaris, \\
\hline 36 & $\begin{array}{l}\text { Euphorbia abbyssinica J.F. } \\
\text { Gmel. }\end{array}$ & & & & & & a \\
\hline BA & Euphorbiaceae, Justicia & Loomii & $\mathrm{T}$ & $\mathrm{D}$ & Seed of J. Schimperiana is crushed & Oral & Rabies \\
\hline 42 & $\begin{array}{l}\text { schimperiana (Nees) T. } \\
\text { Anderson }\end{array}$ & & & & and mixed with water and filtered & & \\
\hline BA & Fabaceae, Acacia abyssinica & Lafftoo & $\mathrm{T}$ & W & Leaf of A. abyssinica is smashed & Dermal & Goiter \\
\hline 26 & Benth. & & & & anc & & \\
\hline BA & Fabaceae, Albizia & Imalaa & $\mathrm{T}$ & W & Root of A. schimperiana and & Nasal & Evil eye \\
\hline 65 & & & & & $\begin{array}{l}\text { Pterolobium stellatum is dried and } \\
\text { powdered. }\end{array}$ & & \\
\hline & & & & & $\begin{array}{l}\text { Root of A.schimperiana } \\
\text { is powdered and the powder is } \\
\text { rolled in clean cloth and tied to the } \\
\text { neck of equines. }\end{array}$ & & Swelling \\
\hline Voucher number & $\begin{array}{l}\text { Family, Genera, species } \\
\text { names }\end{array}$ & Local names & $\begin{array}{l}\text { Growth } \\
\text { habit }\end{array}$ & $\begin{array}{l}\text { Plant type, } \\
\text { cultivated/wild }\end{array}$ & $\begin{array}{l}\text { Part(s) used and preparation } \\
\text { method }\end{array}$ & $\begin{array}{l}\text { Administration } \\
\text { route }\end{array}$ & Disease(s) treated \\
\hline BA & Fabaceae, Calpurnia & Ceeqaa & $\mathrm{SH}$ & W & Leaf of C. subdecandra is smashed & Dermal & Skin diseases \\
\hline 28 & Schweick. & & & & & & \\
\hline
\end{tabular}


Table 1 Medicinal plant used for the treatment of human diseases; scientific name, local name, Habit, part(s) used, method of preparation, administration route and diseases treated (Continued)

\begin{tabular}{|c|c|c|c|c|c|c|c|}
\hline $\begin{array}{l}\text { BA } \\
63\end{array}$ & $\begin{array}{l}\text { Fabaceae, Erythrina } \\
\text { abyssinica Lam. Ex. DC. }\end{array}$ & Beroo & $\mathrm{T}$ & W & $\begin{array}{l}\text { Crushed fresh bark is homogenized } \\
\text { in water }\end{array}$ & Oral & $\begin{array}{l}\text { Abdominal distention, } \\
\text { and cramp }\end{array}$ \\
\hline BA & \multirow{2}{*}{$\begin{array}{l}\text { Fabaceae, Taverniera } \\
\text { abyssinica A. Rich, }\end{array}$} & \multirow[t]{2}{*}{ Dingatanya } & \multirow[t]{2}{*}{$\mathrm{SH}$} & \multirow[t]{2}{*}{ W } & \multirow{2}{*}{$\begin{array}{l}\text { Dried root is fumigated only dry } \\
\text { root is tuting with teelth }\end{array}$} & \multirow[t]{2}{*}{ Oral } & Spiritual disease \\
\hline 18 & & & & & & & Internal Parasite \\
\hline BA & \multirow{2}{*}{$\begin{array}{l}\text { Lamiaceae, Ajuga integrifolia, } \\
\text { Buch.-Hamn. }\end{array}$} & \multirow[t]{2}{*}{ Armaguusa } & \multirow[t]{2}{*}{$\mathrm{H}$} & \multirow[t]{2}{*}{ W } & \multirow{2}{*}{$\begin{array}{l}\text { Leaf of } A \text {. integrifolia is pounded and } \\
\text { mixed with nut oil }\end{array}$} & \multirow[t]{2}{*}{ Oral } & \multirow[t]{2}{*}{ Epilepsy } \\
\hline 29 & & & & & & & \\
\hline BA & \multirow{2}{*}{$\begin{array}{l}\text { Lamiaceae, Clerdendrum } \\
\text { myricoides Hochst }\end{array}$} & \multirow[t]{2}{*}{ Maraasisa } & \multirow[t]{2}{*}{$\mathrm{SH}$} & \multirow[t]{2}{*}{ W } & \multirow{2}{*}{$\begin{array}{l}\text { Leaves of C. Myricoides are extracted } \\
\text { with cold water }\end{array}$} & \multirow[t]{2}{*}{ Oral } & \multirow[t]{2}{*}{ Abdominal distension } \\
\hline 32 & & & & & & & \\
\hline BA & \multirow{3}{*}{$\begin{array}{l}\text { Lamiaceae, Ocimum } \\
\text { gratissimum L. }\end{array}$} & \multirow[t]{3}{*}{ Damakase } & \multirow[t]{3}{*}{$\mathrm{SH}$} & \multirow[t]{3}{*}{ w } & Leaf of $O$. gratissimum is squeezed & Oral & Alergic \\
\hline 11 & & & & & & Nasal & \\
\hline & & & & & & Skin & \\
\hline BA & Lamiaceae, Ocimium & Hancabbii & $\mathrm{H}$ & $\mathrm{D}$ & Leaf of Ocimum lamifolium is & Nasal & Headache \\
\hline 15 & lamifolium Hochst. Ex. Benth. & & & & smashed and sniffed & & \\
\hline Voucher number & $\begin{array}{l}\text { Family, Genera, species } \\
\text { names }\end{array}$ & Local names & $\begin{array}{l}\text { Growth } \\
\text { habit }\end{array}$ & $\begin{array}{l}\text { Plant type, } \\
\text { cultivated/wild }\end{array}$ & $\begin{array}{l}\text { Part(s) used and preparation } \\
\text { method }\end{array}$ & $\begin{array}{l}\text { Administration } \\
\text { route }\end{array}$ & Disease(s) treated \\
\hline$\overline{B A}$ & Loganiaceae, Buddleja & Hanfaaree & $\mathrm{T}$ & W & Leaf of B. polystachya is chewed and & Optical & Eye disease \\
\hline 31 & polystachya Fresen. & & & & spitted on cattle eye. & & \\
\hline BA & Melianthaceae, & Lolchiisaa & $\mathrm{SH}$ & W & Leafy-Stem tip of B. abyssinica is & Dermal & Wound \\
\hline 12 & & & & & squeezed and creamed on wound & & \\
\hline BA & Moraceae, Ficus sycomorus L. & Odaa & $\mathrm{T}$ & W & Sap is collected from bark surface & Dermal & Hepatitis \\
\hline 47 & & & & & $\begin{array}{l}\text { of Ficus sycomorus and creamed on } \\
\text { skin. }\end{array}$ & & \\
\hline BA & Muluginaceae, Glinus lotoides & Mataharree & $\mathrm{H}$ & W & Leafy-stem of G. lotoides is crused, & Oral & Tape worm \\
\hline 23 & L. & & & & pwodered and liquified. & & \\
\hline BA & Myrsinaceae, Maisa & Abbayii & $\mathrm{T}$ & W & Bark of M. lanceolata is pounded & External, & Elephantiasis \\
\hline 82 & & & & & & & \\
\hline BA & Myrtaceae, Eucalyptus & Bargamoo Adii & $\mathbf{T}$ & D & Leaf of E. globules is boiled in water & Nasal & Influenza \\
\hline 48 & & & & & & & Allergic \\
\hline BA & Poaceae, Cynodon dactylon L. & Coqosa adii & $\mathrm{H}$ & W & Leafy-stem is harvested and given & Oral & Bone fracture \\
\hline 30 & & & & & for & & \\
\hline BA & Poaceae, Cynodon nemfuensis & Coqorsa gurraacha & $\mathrm{H}$ & W & Crash leaf stem with teeth & Dermal & Tonsillitis \\
\hline
\end{tabular}


Table 1 Medicinal plant used for the treatment of human diseases; scientific name, local name, Habit, part(s) used, method of preparation, administration route and diseases treated (Continued)

\begin{tabular}{|c|c|c|c|c|c|c|c|}
\hline $\mathrm{BA}$ & \multirow{2}{*}{$\begin{array}{l}\text { Phytolaccaceae, } \\
\text { Phytolocca dodecandra, L } \\
\text { 'Hert. }\end{array}$} & \multirow[t]{2}{*}{ Andoodee } & \multirow[t]{2}{*}{$\mathrm{H}$} & \multirow[t]{2}{*}{ W } & \multirow{2}{*}{$\begin{array}{l}\text { Leaf of } P \text {. dodecandra is squeezed } \\
\text { and juice is made }\end{array}$} & \multirow[t]{2}{*}{ Oral } & Sinus \\
\hline 34 & & & & & & & Anemia \\
\hline BA & \multirow{2}{*}{$\begin{array}{l}\text { Plumbaginaceae, Plumbago } \\
\text { zeylanica L. }\end{array}$} & \multirow[t]{2}{*}{ Martus } & \multirow[t]{2}{*}{$\mathrm{H}$} & \multirow[t]{2}{*}{ W } & \multirow{2}{*}{$\begin{array}{l}\text { Leaf of } P \text {. zeylanica is squeezed and } \\
\text { juice is made }\end{array}$} & \multirow[t]{2}{*}{ Oral } & \multirow[t]{2}{*}{ Cancer } \\
\hline 41 & & & & & & & \\
\hline BA & \multirow{2}{*}{$\begin{array}{l}\text { Polygalaceae, Rumex } \\
\text { neppalensis Spreng }\end{array}$} & \multirow[t]{2}{*}{ Tult } & \multirow[t]{2}{*}{$\mathrm{H}$} & \multirow[t]{2}{*}{ W } & \multirow{2}{*}{$\begin{array}{l}\text { Root of } R \text {. nepalensis is pounded } \\
\text { and two cup of tea is taken with } \\
\text { coffee. }\end{array}$} & \multirow[t]{2}{*}{ Oral } & \multirow[t]{2}{*}{ Stomachache } \\
\hline 10 & & & & & & & \\
\hline BA & \multirow{2}{*}{$\begin{array}{l}\text { Polygalaceae, Securidica } \\
\text { longipedunculata Fresen }\end{array}$} & \multirow{2}{*}{$\begin{array}{l}\text { Etsamanaay } \\
\text { (Amharic) }\end{array}$} & \multirow[t]{2}{*}{$\mathrm{T}$} & \multirow[t]{2}{*}{ W } & \multirow{2}{*}{$\begin{array}{l}\text { Root is pounded and mixed with } \\
\mathrm{H}_{2} \mathrm{O}\end{array}$} & \multirow[t]{2}{*}{ Oral } & \multirow[t]{2}{*}{ Intestinal parasite } \\
\hline 13 & & & & & & & \\
\hline BA & \multirow{2}{*}{$\begin{array}{l}\text { Ranunculaceae, Nigella sativa } \\
\text { L. }\end{array}$} & \multirow[t]{2}{*}{ Gurra } & \multirow[t]{2}{*}{$\mathrm{SH}$} & \multirow[t]{2}{*}{ D } & \multirow{2}{*}{$\begin{array}{l}\text { Concoction, dry pounded seed with } \\
\text { pounded dry Brassica juncea and } \\
\text { Echinops kebericho root, powder is } \\
\text { mixed with water }\end{array}$} & Nasal & Headache \\
\hline 22 & & & & & & & \\
\hline BA & Rocaceae, Prunus africana & Hoomii & $T$ & W & Liquid extracts from P. africana bark & Oral & benign prostatic hyperplasia, \\
\hline 37 & (Hook. f.) Kalkman & & & & $\begin{array}{l}\text { is pounded, juiced and drunk for } \\
\text { treatment }\end{array}$ & & prostate gland hypertrophy \\
\hline BA & Rubiaceae, Coffee arabica L. & Buna & $\mathrm{T}$ & D & Roust the seed, pounded and mixed & Oral & Diarrhea \\
\hline 20 & & & & & & & \\
\hline Voucher number & $\begin{array}{l}\text { Family, Genera, species } \\
\text { names }\end{array}$ & Local names & $\begin{array}{l}\text { Growth } \\
\text { habit }\end{array}$ & $\begin{array}{l}\text { Plant type, } \\
\text { cultivated/wild }\end{array}$ & $\begin{array}{l}\text { Part(s) used and preparation } \\
\text { method }\end{array}$ & $\begin{array}{l}\text { Administration } \\
\text { route }\end{array}$ & Disease(s) treated \\
\hline$\overline{\mathrm{BA}}$ & Rutaceae, Clausena anisata & Ulumaa'i & $T$ & W & Leaf of C. anisata, Solanecio gigas & Dermal & Skin irritation \\
\hline 39 & (Wild.) Benth. & & & & $\begin{array}{l}\text { and Justicia schimperiana are } \\
\text { pounded together }\end{array}$ & & \\
\hline BA & Rutaceae, Ruta chalepensis L. & Cilaattama & $\mathrm{H}$ & D & Leaf of $R$. chalepensis and leaf of & Oral & Stomacache \\
\hline 44 & & & & & $\begin{array}{l}\text { Vernonia amygdalina are smashed } \\
\text { together and one cup of domestic } \\
\text { alcohol is taken by human }\end{array}$ & & \\
\hline BA & Simarobouceae, Brucea & Qomonyo & $\mathrm{SH}$ & W & Leaf of $B$. antidysenterica is pounded & Dermal & External parasite \\
\hline 44 & antidysentrica Fresen & & & & and & & \\
\hline BA & Solanaceae, Datura & Asaangira & $\mathrm{SH}$ & W & Leafy-stem is squeezed and its drop & Dermal & Wart Toothache \\
\hline 56 & stramonium & & & & prepared with butter & & \\
\hline BA & Solanaceae, Withania & Kumo & $\mathrm{SH}$ & W & Leaf of $W$. somnifera is powdered, & Oral & Malaria \\
\hline 55 & & & & & & & \\
\hline BA & Zingibiraceae, Zingiber & Zinjibila & $\mathrm{H}$ & D & Leafy-Stem is pounded and mixed & Nasal & Influenza Internal Parasite \\
\hline 17 & & & & & & Oral & \\
\hline
\end{tabular}

Keys: H- Herb, SH-Shrub, T-Tee, W, Wild. D-Domesticated.

$\mathrm{BA}=$ Balcha Abera 
Table 2 Traditional medicinal plant preparation methods ranked by 12 local healers in the area

\begin{tabular}{lcccccccccccccc}
\hline Preparation methods & *LH1 & LH2 & LH3 & LH4 & LH5 & LH6 & LH7 & LH8 & LH9 & LH10 & LH11 & LH12 & Total & Rank \\
\hline Powdering & 10 & 9 & 8 & 7 & 9 & 9 & 10 & 10 & 8 & 9 & 10 & 9 & 108 & $1^{\text {st }}$ \\
Pounding & 7 & 6 & 8 & 7 & 7 & 8 & 8 & 7 & 7 & 8 & 6 & 8 & 87 & $2^{\text {nd }}$ \\
smashing & 5 & 5 & 6 & 7 & 5 & 5 & 6 & 4 & 6 & 5 & 7 & 7 & 68 & $3^{\text {rd }}$ \\
Squeezing & 4 & - & 6 & 6 & 4 & 3 & 5 & 3 & 4 & 5 & 4 & 6 & 50 & $4^{\text {th }}$ \\
Chewing & 3 & 4 & 2 & 5 & 3 & 2 & 2 & 3 & 3 & 4 & 5 & 6 & 42 & $5^{\text {th }}$ \\
Crushing & 3 & 2 & 1 & 3 & 2 & 2 & 1 & 2 & 3 & 3 & 2 & 4 & 37 & $6^{\text {th }}$ \\
Dry bath & 2 & 1 & 2 & 2 & 1 & 1 & 3 & 1 & 2 & 1 & 3 & 3 & 22 & $7^{\text {th }}$ \\
Stem bath & 1 & 3 & - & - & - & - & 1 & 1 & 1 & - & - & 2 & 9 & $8^{\text {th }}$ \\
\hline
\end{tabular}

* LH- Local Healer.

rainy seasons. It was also cited that, these are effective for the complete extraction of the potential content of the plant and increase the curative power of the medicine or its efficacy, as both increases the healing power of the remedy through faster physiological reaction. After preparation, the remedies are either used soon or preserved for latter use.

Traditional medicinal plants preservation methods.

The use of plastic bags was ranked 1st by traditional practitioners for the preservation of medicinal plants followed by clay-made containers, cloths sheet, roof hanging and sealed bottles (Table 3 ).

According to the discussions made with traditional healers the preparations made drawn from mixtures of different plant species with different additive substances like honey, sugar, teff flour, butter, soda ash, salt, ground honey, soil and charcoal ash for the treatment of single ailment (data not given). These additive substances had been reported to have double function i.e. to improve flavor and reduce adverse effects such as vomiting and diahrrhoea, and enhance the efficacy and healing conditions.

\section{Indigenous knowledge on the mode of administration}

Methods of administration of traditional medicinal plants prepared products by the local healers/community. The major routes of administration in the study area were reported to be oral, dermal, nasal, anal, auricular and optical. Oral administration was the most cited route (63.9\%), followed by dermal route (23\%) and nasal (10\%). Both oral and nasal routes $(4 \%)$ permit rapid physiological reaction of the prepared medicines with the pathogens and increase its curative power.

\section{Medicinal plants popularity in the community}

The degree of agreement on ranking of ten medicinal plants based on the principle that the plant species are widely known and frequently used for the treatment of a particular ailment among the local community is indicated in Table 4. Glinus lotoides scored the highest point and ranked first followed by Echinops kebericho and Lepidium sativum species as widely known by the large local community and even prepared and used at family level.

\section{Ranking of medicinal plants for malaria treatment}

The highest rank was given for Croton macrostaychs followed by Alium sativum and Carica papaya for malaria treatment by the local healers in the study area (Table 5).

\section{Paired comparison}

Of the medicinal plants reported in the study area to treat Gonorrhea a paired compaison (Table 6) indicates that the highest rank was given for Carissa spinarum followed by Cucurbita pepo to treat Gonorrhea.

\section{Fidelty level index}

Fidelity level (FL), as an estimation healing potential, was determined for all reported medicinal plants. Accordingly, Lepidium sativum and Plumbbago zeylanica were the plants having the highest level values, for their

Table 3 Preference ranking on the knowledge of 12 local healers on preservation methods of medicinal plants

\begin{tabular}{|c|c|c|c|c|c|c|c|c|c|c|c|c|c|c|}
\hline Preservation methods & ${ }^{*} \mathrm{R} 1$ & $\mathrm{R} 2$ & R3 & R4 & R5 & R6 & R7 & R8 & R9 & R10 & R11 & $\mathrm{R} 12$ & Total & Rank \\
\hline Clay- & 5 & 5 & 4 & 4 & 3 & 5 & 5 & 4 & 4 & 5 & 5 & 5 & 54 & 2 \\
\hline Container & 5 & 5 & 5 & 5 & 4 & 4 & 5 & 5 & 5 & 5 & 5 & 5 & 58 & 1 \\
\hline Plastic bags & 3 & 4 & 5 & 3 & 4 & 3 & 3 & 3 & 2 & 4 & 4 & 4 & 42 & 4 \\
\hline Roof hanging & 4 & 4 & 4 & 3 & 5 & 4 & 5 & 3 & 5 & 3 & 5 & 5 & 50 & 3 \\
\hline Cloths sheet & 2 & 1 & 1 & 2 & 2 & 1 & 2 & 1 & 2 & 2 & 1 & 3 & 20 & 5 \\
\hline
\end{tabular}


Table 4 Ranking of 10 medicinal plants known in the study area by the local community as responded by 12 informants

\begin{tabular}{|c|c|c|c|c|c|c|c|c|c|c|c|c|c|c|}
\hline Species scientific name(s) & *R1 & R2 & R3 & R4 & R5 & R6 & R7 & R8 & R9 & R10 & R11 & R12 & Total & Rank \\
\hline Glinus lotoides & 10 & 9 & 8 & 8 & 9 & 9 & 10 & 9 & 9 & 10 & 8 & 9 & 108 & 1 \\
\hline Echinops kebericho & 9 & 8 & 10 & 8 & 7 & 7 & 9 & 7 & 9 & 8 & 6 & 8 & 96 & 2 \\
\hline Brucea antidysentrica & 5 & 6 & 7 & 5 & 8 & 6 & 6 & 7 & 6 & 7 & 6 & 6 & 75 & 5 \\
\hline Embelia schimperi & 4 & 5 & 6 & 7 & 5 & 4 & 3 & 5 & 4 & 3 & 5 & 6 & 57 & 9 \\
\hline Allium sativum & 8 & 7 & 6 & 8 & 6 & 8 & 10 & 6 & 8 & 7 & 8 & 7 & 89 & 3 \\
\hline Taverniera abyssinica & 5 & 6 & 4 & 7 & 6 & 6 & 7 & 5 & 5 & 7 & 6 & 5 & 69 & 6 \\
\hline Vernonia amygdalina & 4 & 5 & 5 & 6 & 7 & 4 & 5 & 6 & 7 & 4 & 4 & 5 & 62 & 8 \\
\hline Croton macroststchyus & 6 & 7 & 5 & 5 & 6 & 4 & 6 & 5 & 5 & 5 & 5 & 6 & 65 & 7 \\
\hline Ocimum gratissimum & 4 & 6 & 7 & 7 & 4 & 8 & 3 & 2 & 1 & 3 & 5 & 7 & 56 & 10 \\
\hline Ocimum sanctum & 6 & 7 & 7 & 5 & 8 & 7 & 6 & 6 & 5 & 7 & 4 & 8 & 76 & 4 \\
\hline
\end{tabular}

${ }^{*} R=$ Respondent.

use to treat infectious and metaboilc diseases, each scoring 100\%, followed by Euphorbia abyssinica (93\%) (Table 7).

\section{Treated disease categories versus medicinal plants}

Of the total number of medicinal plants reported by local healers $48 \%$ ( $n=24$ species) were used for the treatment of infectious diseases followed by the $20 \%$ (10 species) for two or more diseases and non-infections (Figure 2).

\section{Medicinal plants versus degree of accessibility in the} study area

The availability status of reported medicinal plant species in the study area was analyzed using an Availability Index (AI) categories developed by [20]. Accordingly, one species namely Prunus africana was reported as "Rare" 1
(2\%) Followed by "Middle" 21 (42\%), "common" 15 (30\%), and "vey common" 12 (24\%) species (Figure 3).

\section{Knowledge transfer status among different age groups} and educational levels

A significant difference $(\mathrm{p}<0.05)$ was observed in naming medicinal plants between student informants (of higher institution, 9-12 Grades who were from rural) and the rest of educational levels (both from urban and rural students). Thus, significantly higher average number of medicinal plants $(\mathrm{p}<0.05)$ were reported by informants of higher institution $(14.3 \pm 34)$ and 9 to12 Grades $(12.12 \pm 23)$ who were from rural than all the rest of educational levels. Significantly higher average number of plants $(\mathrm{p}<0.05)$ was also reported by informants of 25 to 32 age groups (11.6 \pm

Table 5 Preference ranking of 5 selected medicinal plants on their degree of treating malaria as perceived by 12 local healers

\begin{tabular}{|c|c|c|c|c|c|}
\hline Respondents & Lepidium sativum & Croton macrostaychs & Allium sativum & Carica papaya & Vernonia amygdalina \\
\hline${ }^{*} \mathrm{R} 1$ & 5 & 5 & 8 & 5 & 0 \\
\hline $\mathrm{R} 2$ & 2 & 4 & 6 & 7 & 3 \\
\hline R3 & 0 & 6 & 4 & 5 & 5 \\
\hline R4 & 8 & 5 & 5 & 7 & 2 \\
\hline R5 & 5 & 9 & 3 & 6 & 3 \\
\hline R6 & 4 & 5 & 6 & 4 & 6 \\
\hline R7 & 2 & 6 & 5 & 3 & 5 \\
\hline R8 & 6 & 5 & 5 & 5 & 5 \\
\hline R9 & 5 & 7 & 7 & 6 & 7 \\
\hline R10 & 2 & 8 & 8 & 4 & 8 \\
\hline R11 & 3 & 8 & 6 & 4 & 6 \\
\hline $\mathrm{R} 12$ & 4 & 9 & 5 & 6 & 5 \\
\hline Total & 46 & 77 & 68 & 62 & 51 \\
\hline Rank & $5^{\text {th }}$ & $1^{\text {st }}$ & $2^{\text {nd }}$ & $3^{\text {rd }}$ & 4 th \\
\hline
\end{tabular}

${ }^{*} R=$ Respondent. 
Table 6 Paired Comparison of 6 medicinal plants in the treatment of Gonorrhea as indicated by 12 respondents

\begin{tabular}{lcccccccc}
\hline Species & \multicolumn{10}{c}{ R1-R12 } \\
\hline Carissa spinarum & - & Cs & Cs & Cs & Cs & Cs & 5x & $\mathbf{1}$ \\
Crateva adonsani & - & - & Ca & Ca & Ca & Kd & 3x & 3 \\
Croton macrostachys & - & - & - & Cp & Cp & Kd & 0x & 6 \\
Cucurbita pepo & - & - & - & - & Cp & Cp & 4x & 2 \\
Euphorbia abyssinica & - & - & - & - & - & Ea & $\mathbf{1 x}$ & $\mathbf{5}$ \\
Kalanchoe densiflora & - & - & - & - & - & - & $\mathbf{2 x}$ & $\mathbf{4}$ \\
\hline
\end{tabular}

43) while there was no significant difference $(\mathrm{P}>0.05)$ between 9-17 and 18-24 age groups (Tables 8 and 9).

\section{Discussion}

This study revealed 49 medicinal plant species representing 31 families and 43 genera used to treat various human ailments. Of these, 13 species were in common with [21], 14 with [13], 15 with [22]. Three species that are common with [23] are known to be used in the medicinal flora of other African countries. In this study, Family Fabaceae was represented by 5 species followed by 4 species of Asteraceae, and Lamiaceae each and 3 species of Euphorbiaceae. Fabaceae, Asteraceae, and Lamiaceae are among the most represented families in the flora of Ethiopia and Eretria ([24-26]. This study shows that the highest percentage of medicinal plants was obtained from wild while the rest were from home garden. In agreement with this study, similar percentage of medicinal plant species reported from different parts of the country by [23,27-29]) were from natural vegetation.

Analysis of growth habit of medicinal plants in this study indicated that there was no such difference especially in the proportion of herbs and trees. The distribution of similar proportion of growth forms is an indication of the harmonious growth of indigenous forest species different from the arid and semiarid regions reported by various authors [6-33].

Analysis of data on plant parts used indicated that leaf is the major part widely employed by local healers in the preparation of remedies followed by root. Previous reports in Ethiopia [15-22,24-26,30-33]. have also shown that

Table 7 Fidelity level values of medicinal plants cited by 12 or moe infomants for being used against a given major ailment category

\begin{tabular}{lccccc}
\hline Medicinal plant & Major ailments category & Ip & Iu & FL & FL\% \\
\hline Lepidium sativum & Infectious (malaria, Influenza) & 12 & 12 & 1 & 100 \\
$\begin{array}{l}\text { Euphorbia } \\
\text { abbyssinica }\end{array}$ & $\begin{array}{c}\text { Sexual diseases } \\
\text { (Gonorrhea, Syphills) }\end{array}$ & 14 & 15 & .93 & 93 \\
$\begin{array}{l}\text { Croton } \\
\text { macrostachyus }\end{array}$ & $\begin{array}{c}\text { Abdominal (Ameboic dysenty, } \\
\begin{array}{l}\text { Plumbago zeylanica } \\
\text { Ascaisis, Tape worm) }\end{array}\end{array}$ & 16 & .81. & 81 \\
& $\begin{array}{c}\text { Metabolic (Breast cancer, } \\
\text { blood pressure) }\end{array}$ & 12 & 12 & .1 & 100 \\
\hline
\end{tabular}

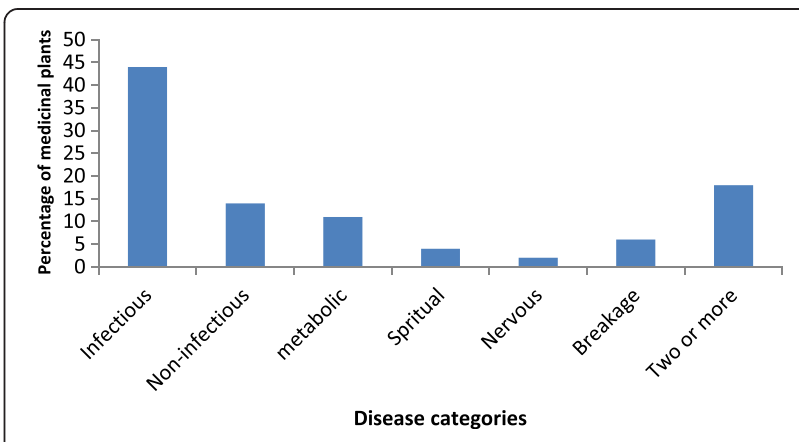

Figure 2 Frequency distribution of medicinal plants used in the treatment of diseases in the study area.

leaves were the most commonly used to treat various health problems Given the highest frequency of leaves used for medicinal purposes in the study area threat to the destruction of medicinal plants especially to trees and shrubs was found to be minimal, as high threat to the mother plant comes with root, bark and leafy-stem harvests. However, [34] indicated that the harvest of leaves has also a threat to the deterioration of medicinal plants since the removal of leaves limits the transformation of vegetative to reproductive development sucha as flower production and fruit/seed set, which in its turn limits the natural/wild regeneration of plants.

The dependency of local people on fresh materials in the study area including the removal of fresh barks and leaves put the plants under serious threat than the dried form, as fresh materials are harvested directly and used soon with its extra deterioration with no chance of preservation i.e. not stored for latter use. However, during this survey local healers argue that fresh materials are effective in treatment as the contents are not lost before use compared to the dried forms. The livelihood of most traditional healers relied on fresh materials that had aggravated the decline of rare medicinal plants from the study area. Traditional practitioners were collecting medicinal plants with less attention than would be preferred from viewpoint of conservation of plant resource.

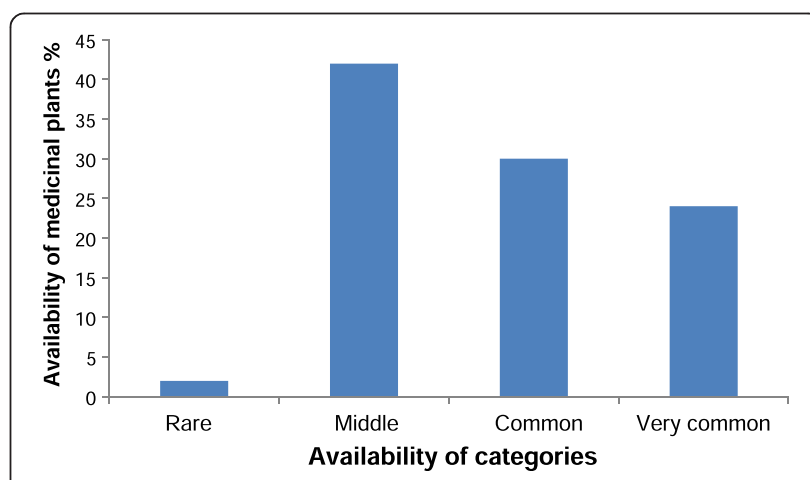

Figure 3 Availability of medicinal plants in the study area. 
Table 8 Indigenous transfer of medicinal plants knowledge among different age groups of healers' family members

\begin{tabular}{lccccccccccccccccc}
\hline $\begin{array}{l}\text { Age } \\
\text { group }\end{array}$ & $\begin{array}{l}\text { Age stages } \\
\text { local name }\end{array}$ & \multicolumn{1}{c}{ R1 } & R2 & R3 & R4 & R5 & R6 & R7 & R8 & R9 & R10 & R11 & R12 & R13 & R14 & R15 & Mean \\
\hline $9-16$ & Foollee & 1 & 2 & 1 & 3 & 2 & 2 & 2 & 3 & 2 & 2 & 4 & 3 & 2 & 1 & 1 & $2 \pm 34^{a^{* *}}$ \\
$17-24$ & Qondaala & 3 & 5 & 4 & 5 & 6 & 5 & 4 & 4 & 3 & & 5 & 4 & 3 & 2 & 4 & $4 \pm 34^{\mathrm{a}}$ \\
$25-32$ & Kuusaa & 14 & 13 & 16 & 15 & 8 & 9 & 6 & 15 & 16 & 18 & 13 & 11 & 8 & 7 & 5 & $11.6 \pm 43^{\mathrm{b}}$ \\
\hline
\end{tabular}

*) Means with standard deviations within the same column followed by different letters $(a-b)$ are significantly different $(P<0.05)$.

Sofowora [23] has reported that the uses of fresh medicinal plants are more effective than other parts.

Of the major disease categories in the study area, infectious diseases are mainly treated traditionally using the large number of medicinal plants. This may be due to the distribution of various pathogens as a result of less sanitation and control measures in developing countries. This could also demonstrate the effort of local healers in searching out more and appropriate medicinal plant species for treatment of such diseases.

According to the informants, the majoity of medicinal plant parts of the study area are prepared either in combination with other medicinal plant parts or with other additives such as boiled coffee, honey and local bevereages (tella) for different purposes (either to increase the healing potential or to improve the flavour and taste or to avoid abdominal discomfort) $[27,28]$. For instance, a traditional medicine applied to treat tape worm infection is prepared by the combination of several medicinal plant parts ( Example, Hagenia abyssinica, Glinus lotoides) with other additives such as local beverages and salt.

As indicated by preference ranking in this study, pounding and powdeing were the most frequently used methods of remedy preparation followed by presering in plastic bags as the most suitable preservation method in the study area. According to the informants' response different methods of remedy preparation and prespervation depend upon an equipment used, prepared and preserved plant parts, temperature and preservation period. Regarding the popular medicinal plants in Ghimbi District as ranked by informants through preference ranking method
Glinus lotoides was the most widely known not only by the local practioniers but also among the large local community of the study area in the treatment of tapeworm infection, followed by Echinops kebericho and Allium sativum. In contrast, [29] have recently reported that among 9 medicinal plants Croton macrostachys was the most popular in the treatment of the same (tapeworm) infection followed by Cucumis sp. Various authors have also reported the existence of popular medicinal plants in different regions of the country such as Cucumis pastulatus for Tuberculosis, Ocimum urtitolum, Rumex abyssinicus, Solanum incanum, Vernonia amygdalina to treat "michi", gonorrhea, toothache and urine retention, respectively [27-29]. In other study reports conducted by [35] and [36] using paired comparison, preference ranking and direct matrix Allium sativum was found to be the most preferred in the treatment of malaria in the northern part of the country. Of the 9 medicinal plants ranked in the study conducted by [37] in Nigeria Azadirachta indica was reported as a prime candidate for investigation, as it recorded the highest rank by the informants. Over 1,200 plants belonging to 160 families were reported [38] to be used traditionally for the treatment of malaria. Since then the number of species has increased substantially due to the increasing worldwide interest in anti-malarial plants.

Of six medicinal plants, the highest rank was given for Carrisa spinarum followed by Curcubita pepo in the treatment of Gonorrhoea. The study conducted by [39] on antigonorrhoeal activity of some medicinal plants showed that significant antigonnorrhoeal activity was exhibited by methanol extracts of some plants, which

Table 9 Indigenous transfer of medicinal plants knowledge among family members and relative of healers with different educational level

\begin{tabular}{|c|c|c|c|c|c|c|c|c|c|c|c|c|c|c|c|c|c|}
\hline Educational level & Residence & R1 & R2 & R3 & R4 & R5 & R6 & R7 & R8 & R9 & R10 & R11 & R12 & R13 & R14 & R15 & Mean \\
\hline \multirow[t]{2}{*}{$0-4$} & Rural & 4 & 5 & 6 & 7 & 4 & 3 & 6 & 2 & 4 & 2 & 4 & 3 & 5 & 5 & 4 & $4.27 \pm 0.14^{\mathrm{a}^{*}}$ \\
\hline & Urban & 3 & 2 & 2 & 2 & 4 & 4 & 3 & 3 & 5 & 4 & 4 & 5 & 4 & 5 & 3 & $3.53 \pm+23^{a}$ \\
\hline \multirow[t]{2}{*}{$5-8$} & Rural & 5 & 3 & 5 & 6 & 5 & 4 & 6 & 4 & 5 & 4 & 4 & 5 & 4 & 4 & 4 & $5.33 \pm 13^{\mathrm{a}}$ \\
\hline & Urban & 3 & 2 & 5 & 1 & 4 & 4 & 6 & 3 & 5 & 4 & 2 & 5 & 4 & 3 & 4 & $3.67^{\mathrm{a}} \pm 34^{\mathrm{a}}$ \\
\hline \multirow[t]{2}{*}{$8-12$} & Rural & 15 & 14 & 12 & 10 & 9 & 10 & 10 & 12 & 11 & 13 & 14 & 12 & 13 & 11 & 14 & $12.12 \pm 23^{\mathbf{b}}$ \\
\hline & Urban & 5 & 4 & 3 & 7 & 5 & 3 & 7 & 6 & 5 & 3 & 4 & 7 & 8 & 2 & 4 & $4.9 \pm 14^{a}$ \\
\hline \multirow[t]{2}{*}{ Higher Institution } & Rural & 16 & 18 & 13 & 12 & 11 & 14 & 15 & 14 & 13 & 13 & 18 & 19 & 12 & 15 & 12 & $14.3 \pm 34^{b}$ \\
\hline & Urban & 5 & 6 & 4 & 7 & 6 & 9 & 5 & 6 & 5 & 5 & 7 & 6 & 5 & 10 & 8 & $6.31 \pm 23^{a}$ \\
\hline
\end{tabular}

*Means with standard deviations within the same column followed by different letters $(a-b)$ are significantly different $(P<0.05$. 
contain bactericidal properties that stimulate the immune system to create more resistant to infection. The differences of plant species used in the treatment of the same ailment in fact depends on the availability of plant species in a particular area and cultural knowledge of particular ethnic groups.

Fidelity level (FL), as an estimation healing potential, was determined for some medicinal plants. Accordingly, Lepidium sativum and Plumbbago zeylanica were the plants having the highest level values, for their use to treat infectious and metaboilc diseases. Trotter and Logan [40], plants scoring higher informant consensus values are thought to have better potency having biologically active ingredients in treatment as compsred to plants with less informant consensus values.

The availability status of reported medicinal plant species in the study area was analyzed using an Availability Index (AI) categories developed by [20]. Accordingly, one species was reported as "Rare "followed by "Middle" 21 (45\%), "common" 15 (31\%), and "vey common" 12 (24\%) species. In this study, about $47 \%$ of medicinal plant parts including root, leafy-stem and bark were reported to be used as a source of treatments. According to [22] ) medicinal plant harvests that mainly involve roots, stems and barks have serious effect on the survival of mother plants. The endangered threat status of Prunus africana throughout African counties resulted from the wide exploitation of its bark both as a source of traditional medicine and development of synthetic drug for the treatment of benign prostatic hyperplasis (BHP) and prostate gland hypertrophy (PGH). The elders of the local community of the study area expressed their great fear that the previous custom of replantation of forest species is declining by current generation. Medicinal plants are directly harvested and processed when only needs arise. Moreover, in Ethiopia the use of wild or uncultivated plants is a common custom and this has been accelerating the deterioration of useful plant population in addition to agricultural expansion accompanied by wide cutting original forest species and environmental degradation. Several studies also indicated $[8,15,41]$ that a growing investment in agriculture became the major threat for the deterioration of the population of medicinal plants in general and herbs. Study by [15] also reported that the use for firewood and construction as well as agricultural expansion were the main causes for the depletion of medicinal plants in the study area.

Regarding the current transfer of indigenous knowledge in generation in the study area, this study revealed that significantly higher average number of medicinal plants $(\mathrm{p}<0.05)$ were reported by informants of rural students and 25-32 age groups. This result confirmed that the traditional knowledge (TBK) is declined from elder to younger age groups. On top of this, during specimen collection, interview and field visits elders express their interest by demonstration how to collect, process, administer, and prescribe medicinal plants and with great beliefs of the traditional medicine on its effectiveness on treating the diseases while the young generation showed low participation in all aspects. Thus, decreasing positive attitude towards use of medicinal plants in traditional medicine by young generation indicate the loss of vital indigenous knowledge. Giday [40] conducted similar study using the informants of Zay Ethnic group in Ethiopia came up with $90 \%$ of the elders above 40 years possessed with enough knowledge in medicinal plants whereas $55 \%$ of the youth informants between 18 and 40 years old were without any knowledge of medicinal plants. Study conducted by [42] in Cameon reported that most young people in urban areas were not interested in the use of traditional medicine due to influence of western culture; considering that traditional medicine is superstitious, which is mainly used by poor and uneducated people. On the other hand, most of the elders kept their knowledge secrecy to generate income and to get sustainable respect from their surrounding community. More0ver, the decline of the traditional knowledge in generation is due to the due to interference of and shifts to the use of more synthetic drugs not only in the urban but also extending to the rural areas. Various reported studies indicate that the absence of formal education in traditional knowledge in developing nations is another factor for the decline of indigenous knowledge $[43,44]$. Moreover, most of the African modern health professionals greatly undermine the contribution of traditional medicine in health care system while the scientists of developed nations intensively search for medicinal plants to seek a solution for the old and newly rising diseases. All these factors may result to a loss of this rich and useful knowledge which has been accumulated over many generations.

\section{Conclusion}

This study showed the wide use of medicinal plants in Ghimbi District in meeting the primary healthcare needs of the Oromo community of the study area. A limited access to modern healthcare facilities could be considered as the main factors for the continuation of the traditional practice. The medicinal plants in the area include all growth forms with almost equal proportion which could be attributed to their abundance in humid areas as compared to arid and semi arid regions. Newly harvested plant materials are mostly used in the preparation of remedies is an indication of the availability of copious plant materials in the vicinity. The medicinal plants in the study area such as Glinus lotoides (against tapeworm infection), Croton macrostachyus (against malaria) and Allium sativum (against malaria and other diseases) were the ones with most preferred, popular and with highest fidelity level 
(FL) values, an indication of their high healing potential. However, the transfer of indigenous knowledge is declining from generation to generation as a result of oral transmission. Therefore, this study recommends the argent need to incorporate this knowledge into formal education before complete lost.

\section{Competing interests}

The author declares that they have no competing interests.

\section{Acknowledgements}

I would like to thank the Research and Publication Office (RPO) of Jimma University for financial support, traditional healers for providing their own indigenous knowledge without any reluctance and Dr. Chali Fekadu (MD) staff of Ghimbi district Health Station for the information of diagnosed diseases in the study area treated by traditional healers. I would also like to thank Mr. Abdulhakim Ahmed who helped me in mapping the exact study sites.

Received: 1 March 2013 Accepted: 26 February 2014

Published: 8 May 2014

\section{References}

1. Abramov V: Traditional medicine. World Health Org 1996, 134:1-3.

2. Farnsworth NR: The role of Medicinal plants in drug development. In Natural Products and Drug Development. Edited by Krogsgaard-Larsen S, Brogger-Christensen S, Kofod H. Copenhagen: Munksgaard; 1994:34-45.

3. Lee KH: Recent new drugs discovered and developed from Chinese medicine. Biopharma quarterly 1998, 4:12-15.

4. Lee KH: Antitumor agents 195 Anticancer drug design based on plant derived natural products. Biomedical J of Sci 1999, 6:236-250.

5. Lee KH, Morris NSL: Anti-AIDS agents 35 Recent advances in the discovery and development of plant-derived natural products and their analogous as anti-HIV agents. Pure Applied Chem 1999, 19:90-105.

6. Almeida CFC, de Amorin ELC, de Albuquercue UP, Maia MBS: Medicinal plants popularly used in the Xingu region- a semi-arid location in Nortehrneastern Brazil. J Ethnobiol Ethnomed 2006, 2:15-23.

7. Vieura RE, Skorupa LE: Brazilian medicinal plants gene bank. Acto Horticulture 1993, 330:51-58.

8. Bekele E: Study on actual situation of medicinal plants in Ethiopia; 2007:54-60. http://www.endashaw.com.

9. Cunninghum AB: Applied ethnobotany: People, wild plant use and conservation. VA:Earthscan punlications Ltd: London and Sterling; 2001

10. Kelbessa E, Demissew S, Woldu Z, Edwards S: Some threatened Endemic plants of Ethiopia. In The status of some plants in parts of tropical Africa. Edited by Edwards S, Zemede A. East and Central Africa: NAPRECA, No.2. Botany 2000; 1992:35-55.

11. Mekonen A, Bluffstone R: Polices to increase forest cover in Ethiopia. In Proceedings of a Policy Workshop organized by Environmental Economics Policy Forum for Ethiopia (EEPFE): 18-19. Edited by Addis A. Ethiopia, Addis Ababa: Ethiopian Development Research Institute (EDRI); 2007:35-43.

12. Abbink J: Medicinal and ritual plants of the Ethiopian Southwest: an account of recent research. Indi know and Dev Monitor 1995, 3:6-8.

13. Abera B: Medicinal plant used in traditional medicine in Jimma zone, Southwest Ethiopia. Ethiopiopian J of Health Sci 2003, 13:85-94.

14. Yineger $\mathrm{H}$, Yewhalaw $\mathrm{D}$, Teketa D: Ethnomedicinal plant knowledge and practice of the Oromo ethnic group in southwestern Ethiopia. J Ethnobiol Ethnomed 2008, 4:11-18.

15. Tolassa E: Use and management of medicinal plants in Ghimbi District. Southwest Ethiopia: MSc thesis, Addis Ababa University, Biology Department; 2007

16. CSA: Statistical Abstract Addis Ababa, Ethiopia. Federal Democratic Republic of Ethiopia: Central Statistical Authority (CSA); 2003.

17. Martin GJ: Ethnobotany: A method Manual. London: Chapman and Hall; 1995.

18. Alexiades MN: Collecting ethnobotanical data: an introduction to basic concepts and techniques. In Selected Guidelines for Ethnobotanical Research: A Field Manual. Edited by Alexiades MN. New York: The New York Botanical Garden; 1996:52-94.

19. Friedman J, Yaniv Z, Dafni A, Palewitch D: A preliminary classification of the healing potential of medicinal plants, based on the rational analysis of an ethnopharmacological field survey among Bedouins in Negev Desert, Israel. J Ethnopharmacol 1986, 16:275-287.

20. Pieroni A: Evaluation of the cultural significance of wild food botanicals traditionally consumed in north-western Tuscany, Italy. J Ethnobiol 2001, 21:89-104

21. Giday M, Asfew Emqvist T, Woldu Z: An Ethnobotanical study of medicinal plants used by the Zay /people in Ethiopia. J Ethnopharmacol 2003, 85:43-52.

22. Lulekal E: Ethnobotanical study of medicinal plants and floristic composition of the Manna Angatu Moist Montane Forest, Bale. Ethiopia; M.Sc. Thesis. Addis Ababa University, Biology Department; 2005.

23. Sofowara A: Medicinal plants and traditional plants in Africa. Chichester and New York; 1982

24. Flora of Ethiopia and Eritrea: Gentianaceae to Cyclocheilaceae. In The National Herbarium. Volume 5th edition. Edited by Hedberg I, Kelbessa E, Edwards S, Demissew S, Persson E. Uppsala Sweden: Addis Ababa, Ethiopia, and Department of Systematic Botany; 2006.

25. Flora of Ethiopia and Eritrea: Canellaceae to Euphorbiaceae. In The National Herbarium. Volume 2, part 2nd edition. Edited by Edwards S, Tadesse M, Hedberg I. Uppsala Sweden: Addis Ababa, Ethiopia, and Department of Systematic Botany; 1995

26. Flora of Ethiopia and Eritrea: Asteraceae. In The National Herbarium. Volume 4, part 2nd edition. Edited by Hedberg I, Friis I, Edwards S. Uppsala, Sweden: Addis Ababa, Ethiopia, and Department of Systematic Botany; 2004.

27. Balemie K, Kelbessa E, Asfaw Z: Indigenous medicinal plant utilization, management and threats in Fentalle area, Eastern Shewa, Ethiopia. Ethiopian J of Bio Sci 2004, 3:37-58.

28. Temene B: Floristic analysis and ethnobotanical study of the semi-wetland of Cheffa area South Welo. Ethiopia. M.Sc. Thesis: Addis Ababa University, Biology Department; 2002.

29. Ashagre M: Ethnobotanical study of medicinal plants in Guji Agro-pastoralists. Bule Hora District of Borana Zone: Oromia Region, Ethiopia, MSc thesis, Addis Ababa University, Addis Ababa, Biology Department; 2011.

30. Flora of Ethiopia and Eritrea: Poaceae. In The National Herbarium. Volume 7th edition. Edited by Hedberg I, Edwards S. Uppsala Sweden: Addis Ababa, Ethiopia, and Department of Systematic Botany; 1995.

31. Flora of Ethiopia and Eritrea: Hydrocharitaceae to Arecaceae. In The National Herbarium. Volume 6th edition. Edited by Edwards S, Demissew S, Hedberg I. Uppsala, Sweden: Addis Ababa, Ethiopia, and Department of Systematic Botany; 1997.

32. Flora of Ethiopia and Eritrea: Magnoliaceae to Flacourtiaceae. In The National Herbarium. Volume 2, part 1st edition. Edited by Edwards S, Tadesse M, Demissew S, Hedberg I. Uppsala, Sweden: Addis Ababa, Ethiopia, and Department of Systematic Botany; 2000.

33. Flora of Ethiopia and Eritrea: Apiaceae to Dipsacaceae. In The National Herbarium. Volume 4, part 1st edition. Edited by Hedberg I, Edwards S, Nemomissa S. Uppsala, Sweden: Addis Ababa, Ethiopia, and Department of Systematic Botany; 2003.

34. Cunningham A: Applied Ethnobotany: People, Wild Plant Use and Conservation. UK.Dev S.: Earthscan, London; 2001. 1997.

35. Bekalo HT, Woodmatas DS, Woldemariam AZ: An ethnobotanical study of medicinal plants used by local people in the lowlands of Konta Special Woreda, Southern nations, nationalities and peoples regional state, Ethiopia. J of ethnobiology and ethnomedicine 2009, 5:1-15.

36. Berhanu A, Asfaw Z, Kelbessa E: Ethnobotany of plants used as insecticides, repellents and antimalarial agents in Jabitehnan district, West Gojjam_SINET. Ethiopian J of Sci 2006, 29:87-92.

37. Dike P, Obembe OO, Adebiyi FF: Ethnobotanical survey for potential anti-malarial plants in southwestern Nigeria. J Ethnopharmacol 2012. http://dx.doi.org/10.1016/j.jep.201210.002.

38. Willcox ML, Bodeker G: Traditional Herbal Medicines for Malaria. Br Med J 2004, 329:1156-1159.

39. Guta M, Lemma H, Addis G, Urga K, Assefa A, Mohammad E, Gemeda N, Yirsew K, Mudi K, Mammo K: Short communication: Antigonorrheal activities of some traditionally used Ethiopian medicinal plants. Pharmaceutical 2008, 26:65-68.

40. Trotter RT, Logan MH: Informants consensus: a new approach for identifying potentially effective medicinal plants. In Plants in Indigenous Medicine and Diet. Edited by Etkin NL. New York: Redgrave Publishing Company, Bedford Hill; 1986:91-112

41. Giday M: An ethnobotanical study of medicinal plants used by the Zay people in Ethiopia. CBM: sskriftserie 2001, 3:81-99. 
42. Simbo D: An ethnobotanical survey of medicinal plants in Babungo, Northwest Region, Cameroon. J Ethnobiol Ethnomed 2010, 6:8-15.

43. Teshome W: Impacts of Urbanization on the Traditional Medicine of Ethiopia. Anthropologist 2005, 8:43-52.

44. Addis $G$, Abebe $D$, Genebo T, Urga K: Perceptions and practices of modern and traditional health practitioners about traditional medicine in Shirka district, Arisi Zone. Ethiop J Health Dev 2002, 16:19-29.

doi:10.1186/1746-4269-10-40

Cite this article as: Abera: Medicinal plants used in traditional medicine by Oromo people, Ghimbi District, Southwest Ethiopia. Journal of Ethnobiology and Ethnomedicine 2014 10:40.

\section{Submit your next manuscript to BioMed Central and take full advantage of:}

- Convenient online submission

- Thorough peer review

- No space constraints or color figure charges

- Immediate publication on acceptance

- Inclusion in PubMed, CAS, Scopus and Google Scholar

- Research which is freely available for redistribution 